\title{
PERFORMANCE EVALUATION OF A DRYER FOR PROCESSED LOCUST BEAN CONDIMENTS
}

\author{
Adamade, C. A. ${ }^{2}$ and Olaoye, J. 0.1 \\ Department of Agricultural and Biosystems Engineering.University of Ilorin1. \\ National Centre for Agricultural Mechanization, Ilorin. ${ }^{2}$
}

\begin{abstract}
Drying of fresh fermented locust beans condiments is highly important in marketing strategy. Performance test of the dryer for processed locust beans condiments (Iru) was carried out using an instrumented dryer designed and developed, this was used to dry two varieties of fermented locust beans (Iru Woro of initial moisture content of $48.38 \%$ and Iru Pete 49. $20 \%$ ) under three different temperatures $\left(45^{\circ} \mathrm{C}, 50^{\circ} \mathrm{C}\right.$ and $\left.55^{\circ} \mathrm{C}\right)$ for electric heater, $70 \%$ average relative humidity and three categories of Weights $(200 \mathrm{~g}, 300 \mathrm{~g}$ and $400 \mathrm{~g})$ and drying one hour interval. The moisture loss and drying rates were determined for the processed locust beans. The average drying rates ranged from 17.99 to $1.72 \mathrm{~g} / \mathrm{hr}$ and 14.32 to $31.76 \mathrm{~g} / \mathrm{hr}$ for the Iru Woro and Iru Pete respectively. The efficiency of the dryer ranged from $65.71 \%$ - $84.60 \%$ for Iru Woro and $65.60 \%$ - $84.87 \%$ for Iru Pete respectively. The drying rates and efficiency of the dryer were subjected to statistical analysis using $2 \times 3 \times 3$ factorial design to study the effects of these parameters on the drying rates of the dried processed products. These results showed a significant difference in the different varieties dried at $5 \%$ confidence level.
\end{abstract}

Keywords: Performance Evaluation, Efficiency, Drying Rates, Iru Woro, Iru Pete

\section{INTRODUCTION}

Several drying systems have been reported by researchers, but they are mostly solar dryers depending on the climatic conditions (Alonge and Hammed, 2007; Folaranmi, 2009; Amer et.al. 2009; Gatea, 2010). Also some of the dryers constructed were electric dryers, but were mostly tubers and grains crops not specifically for locust beans. Most of the electric dryers constructed were faced with the problem of inaccurate temperature measurements within the drying unit. Opiriairi, (2008) suggested the use of thermocouples instead of thermometers for temperature measurement within the drying unit. Ndukwu (2009) in a study of batch drying methods for cocoa beans provides useful hints on how fermented locust beans can be processed through drying. Ogunleye and Awogbemi (2009) report that, the two methods of preserving and improving the quality of fermented locust beans are drying and salting. When the locust beans seed are boiled and soaked for 12 hours respectively, the fermented seeds were subjected to direct sun drying for 5 days, the result showed that dried salted seeds contain $67.65 \%$ of Protein and dried unsalted sample contains $66.82 \%$ of Protein. 
Hany et al. (2012) conduct an experiment using two convective hot air dryers namely; gas fired hot air dryer and electrically heated hot air dryer. The research was done in terms of drying process, energy consumption and quality of dried onion slices. The choice of energy source was based on the initial moisture content of the crop, the type of crop and how fast one need to dry the product. They explained that air temperatures and air flow velocities affect drying of any product and recommended $50{ }^{\circ} \mathrm{C}$ to $70{ }^{\circ} \mathrm{C}$ of air temperature and air velocities of $0.5 \mathrm{~m} / \mathrm{s}$ to 2.0 $\mathrm{m} / \mathrm{s}$ for drying effectiveness. Muazu et al. (2012) develop a forced air convection dryer with capacity of $20 \mathrm{~kg}$ to dry vegetables. They recommended an average rate of drying to be $7.23 \mathrm{x}$ $10^{4} \mathrm{~kg} / \mathrm{s}$, critical moisture content to be $72 \%$ wet base and temperature range of $35^{\circ} \mathrm{C}$ to $63{ }^{\circ} \mathrm{C}$ for drying fruits and vegetables.

In an attempt to create employment opportunity for people, the evaluation of the dryer is necessary to provide an alternative means of value addition to locust beans processing. The objective of this research work was to carry out performance test on the dryer in order to determine the drying rates and efficiency of a machine for drying of processed locust bean.

\section{The Dryer}

\section{Description of the Dryer}

The dryer consists of drying chamber, trays, chimney, electric heater, blower with centrifugal fan and prime mover, thermostat with probe to get the accurate measurement of the temperature inside the dryer. The dryer has an overall dimension of height $1610 \mathrm{~mm}$, length $600 \mathrm{~mm}$ and width $600 \mathrm{~mm}$. It is heated with one heater of $1.8 \mathrm{KW}$ connected with $2 \mathrm{hp}$ centrifugal fan. Figure 1 shows the pictorial view of the dryer. 


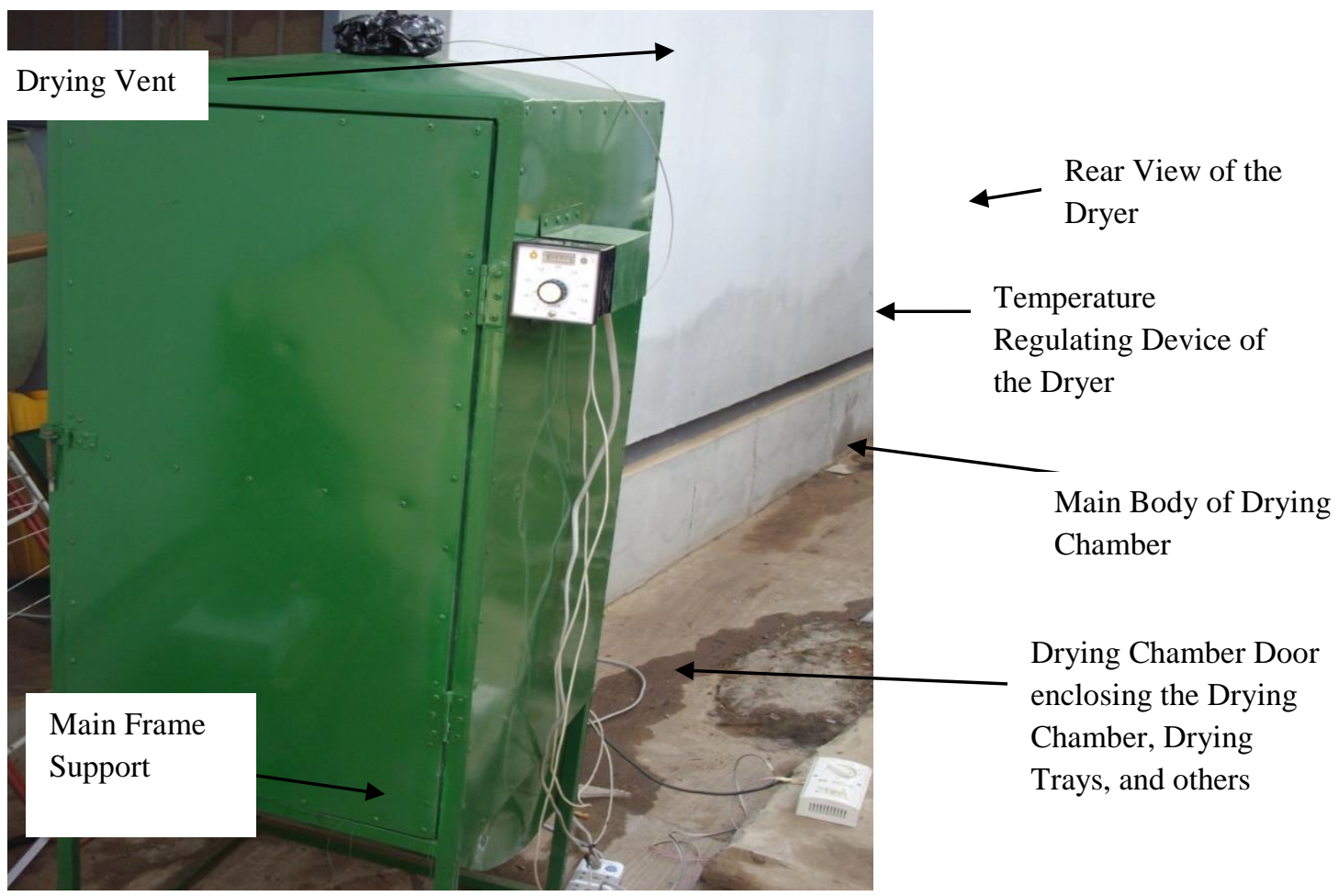

Figure 1: Pictorial View of the Dryer

\section{Working Principle of the Dryer}

The working principle of the dryer followed the steps described below.

i. $\quad$ Connect the heater, thermocouple and the blower to the power source.

ii. Set the thermocouple to the required temperature.

iii. Allow the drying chamber to be heated for 30 minutes.

iv. Arrange the materials on the trays inside the drying unit.

v. Turn on the switches for the heater, thermocouple and blower.

In order to properly monitor the inner temperature of the dryer, a thermocouple with probe was fixed by the side of the drying chamber and the probe passed through the chimney into the drying chamber.

\section{Materials}

\section{MATERIALS AND METHODS}

Testing materials for the dryer included the fermented locust beans (two types; Iru Woro and Iru $P e t e)$, Electricity, mercury-in-bulb thermometer, digital anemometer, thermo - hydrometer, sensitive weighing scale. 


\section{Methods \\ Drying Procedures}

The dryer was pre-heated for 30 minutes in order to establish steady state conditions to the desired temperature of $45^{\circ} \mathrm{C}$ using the temperature controller while the samples were prepared accordingly (Iru Woro $\mathrm{V}_{1}$ and Iru Pete $\mathrm{V}_{2}$ ). The timing for the pre-heating of the dryer was dictated by the rate of heat flow and the designed capacity of the drying chamber (Earle and Earle. 2004). Labels were randomly placed on trays with tags of the two treatments, Sw 1- 3 for Iru Woro, Sp 13 for Iru Pete, Qw1-3 for weight of the Iru Woro and Qp1 - 3 for weight of Iru Pete. The freshly fermented locust beans were spread on the trays and inserted into the dryer. Thereafter, the fan was switched on and set to a velocity of $0.5 \mathrm{~m} / \mathrm{s}$ using the fan regulator. A digital anemometer was used to measure the speed of the fan and immediately after loading, the initial condition of the environment and the drying chamber was determined. The weight was checked every one hour using an electronic weighing balance throughout the drying period. Temperature of the exhaust air was determined and recorded using a thermocouple with a probe and mercury inbulb thermometer was used to calibrate temperature on the different tray. The procedure was repeated at $50^{\circ} \mathrm{C}$ and $55^{\circ} \mathrm{C}$ temperature respectively.

\section{Evaluation of Drying Rate}

The knowledge of the length of time needed to dry a product from initial moisture content $m_{i}$ to final moisture content $m_{f}$ and the rate at which drying is taking place.

The drying rate is calculated as expressed in equation 1

$$
\mathrm{R}=\left(\frac{d M}{d t}\right)=\frac{m_{i}-m_{f}}{t}
$$

Where,
$\mathrm{R}$ is the drying rate in $\mathrm{g} / \mathrm{hr}$, $\mathrm{d}_{\mathrm{M}}$ is the change in mass $\mathrm{g}$, $\mathrm{d}_{\mathrm{t}}$ is the change in time $\mathrm{hr}$, $\mathrm{t}$ is the total time $\mathrm{hr}$, $m_{i}$ is the initial mass of locust beans samples $g$ $\mathrm{m}_{\mathrm{f}}$ is the final mass of locust beans samples $\mathrm{g}$.

\section{Evaluation of Dryer Efficiency $D_{E}(\%)$ :}

This indicates the quantity of fermented locust beans seeds that are being dried by the machine and it is expressed in percentage, this shows how efficiently the machine carried out the drying of the sample. It is expressed as shown in equation 2 . 


$$
D_{E}=\frac{W_{3}}{W_{2}} \times 100(\%)
$$

Where,

$$
\begin{aligned}
& W_{2}(\mathrm{~kg}) \text { is Weight of fresh locust beans seed } \\
& W_{3}(\mathrm{~kg}) \text { is Weight of dried Locust beans seeds. }
\end{aligned}
$$

\section{RESULTS AND DISCUSSION}

The effect of Drying Temperature Quantity Dried and Drying Time on the Drying Rates of Fermented Locust beans condiment Iru Woro and Iru Pete. Figures 2 to 7 showed the effects of drying temperature on the drying rates for the different varieties of locust beans samples with different ranges of quantity dried. The drying rates of sample dried at $45^{\circ} \mathrm{C}$, for $200 \mathrm{~g}$ and $300 \mathrm{~g}$ had the lowest values as compared to the $400 \mathrm{~g}$ with the highest value of $48.67 \mathrm{~g} / \mathrm{hr}$ at this temperature. After the first one hour, drying at $50{ }^{\circ} \mathrm{C}$ attained for both varieties, the highest drying rate of $39.67 \mathrm{~g} / \mathrm{hr}$ and $37 \mathrm{~g} / \mathrm{hr}$ both for weight $300 \mathrm{~g}$ (Figures 2 and 5). After 2 hours for $400 \mathrm{~g}$, the drying rates raised at drying temperature $50^{\circ} \mathrm{C}$ from $43.17 \mathrm{~g} / \mathrm{hr}$ (Iru Woro) to $47.17 \mathrm{~g} / \mathrm{hr}$ (Iru Pete), (Figures 4 and 7). It was observed that for $400 \mathrm{~g}$ of Iru Woro dried at $55{ }^{\circ} \mathrm{C}$, the drying rate obtained a value of $44.22 \mathrm{~g} / \mathrm{hr}$ after $3 \mathrm{hrs}$ of drying and later reduced until $8 \mathrm{hrs}$. The Iru Pete had drying rate that increased initially and later lowered for all the levels of quantity dried. The drying rates at the three drying temperatures follow the same trend.

It was observed that the drying rates decreased as the drying temperature increased and drying time reduces for both types of the fermented locust beans. At higher temperature the heat energy increases and this is in conformity with the findings of Omodara et al., (2011); Mujjafat and Sankat, (2005); Kilic, (2009). The statistical analysis revealed that the drying rates of the two varieties were significantly different at $5 \%$ confidence level due to the difference in the mean value.

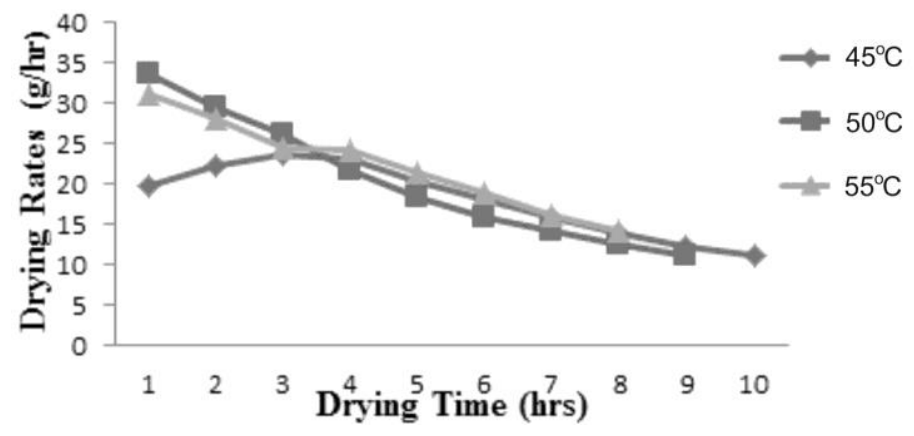

Figure 2: The Effects of Drying Temperature and Time on Drying Iru Woro Rate 


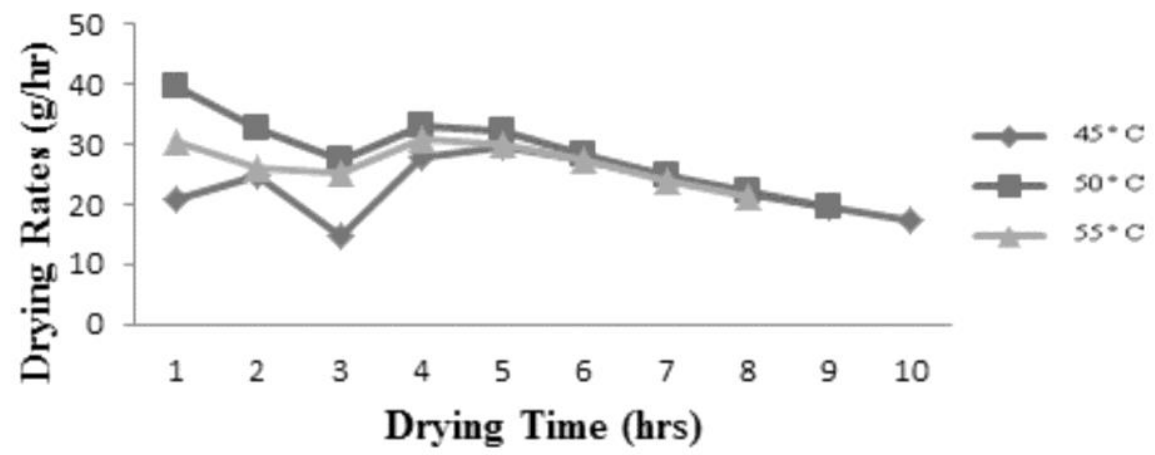

Figure 3: The effects of Drying Temperature and Time on Drying Rate for $300 \mathrm{~g}$ Iru Woro

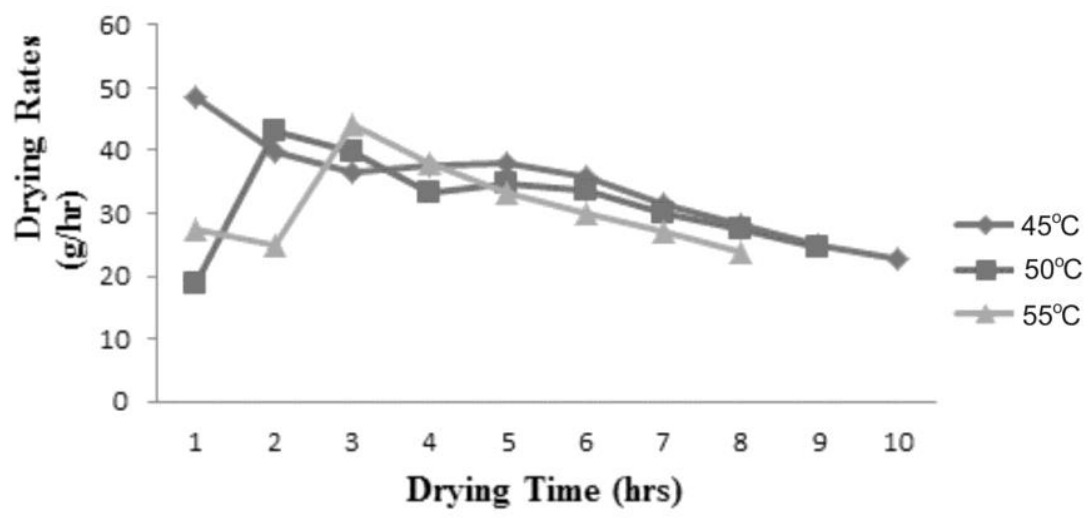

Figure 4: The effects of Drying Temperature and Time on Drying Rate for $400 \mathrm{~g}$ Iru Woro

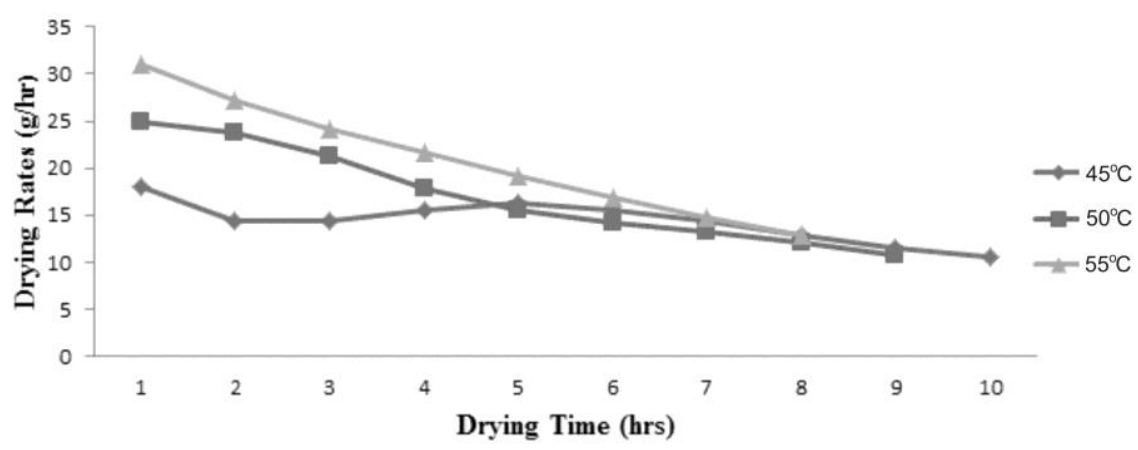

Figure 5: The effects of drying temperature and Time on drying rates for $200 \mathrm{~g}$ Iru Pete 


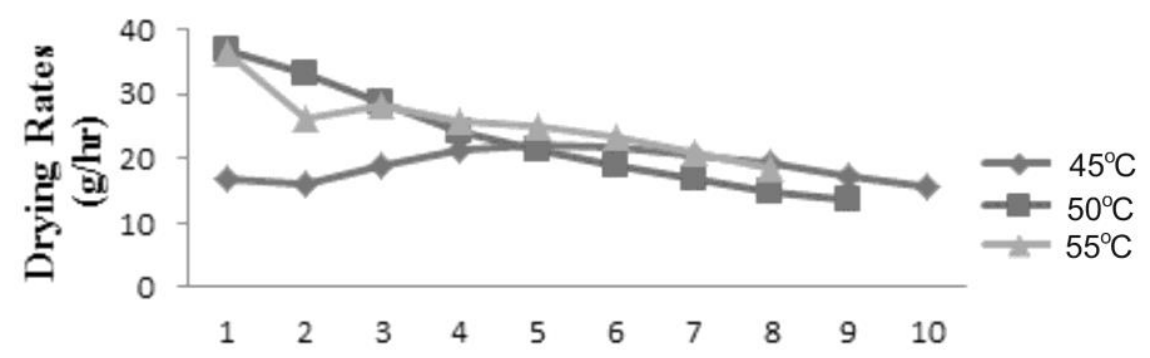

\section{Drying Time (hrs)}

Figure 6: The effects of drying temperature and Time on drying rates for $300 \mathrm{~g}$ Iru Pete

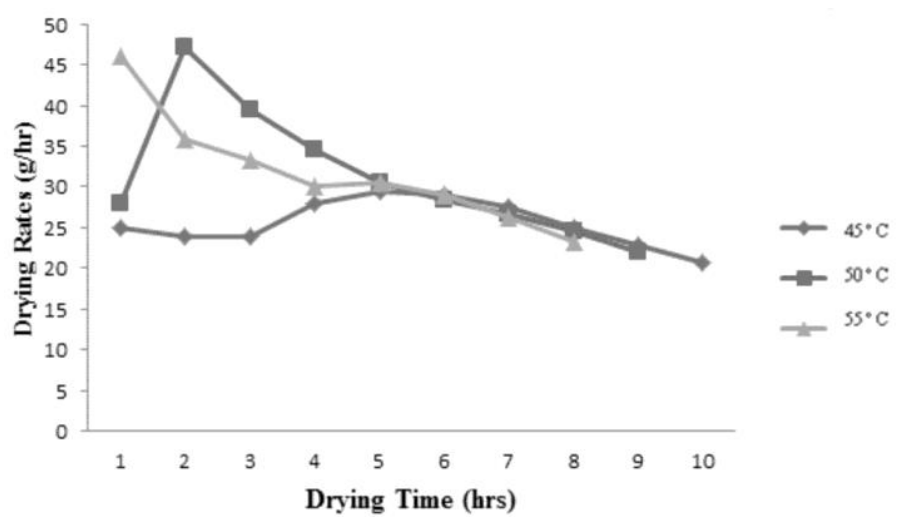

Figure 7: The effects of drying temperature and Time on drying rates for $400 \mathrm{~g}$ Iru Pete

\section{Drying Efficiency}

The effects of Drying Temperature on the Drying Efficiency of the Dryer for Processed Condiments.

From Figure 8, the ranges of drying efficiency obtained are from $65.71 \%-84.60 \%$ depending on the quantity dried. It was shown that, at $45{ }^{\circ} \mathrm{C}$ drying temperature, the mean efficiency increased with the weight as compared to $50^{\circ} \mathrm{C}$ and $55^{\circ} \mathrm{C}$ that has reduced efficiency in relation to the weight dried. It was observed that at $50^{\circ} \mathrm{C}$, the Iru Woro dried better with the highest efficiency of $84.60 \%$. This showed that the dryer performs efficiently and effectively for locust beans when dried at $50{ }^{\circ} \mathrm{C}$. For all the quantity dried for Iru Woro, the mean drying efficiency showed differences. 


\section{The effects of Drying Temperature on the Drying Efficiency of the Dryer for Iru Pete}

It was observed from Figure 9 that the drying temperature of the dryer had significant effects on the efficiency of the dryer. For this type of locust beans, the sample dried at $45^{\circ} \mathrm{C}$ had the lowest efficiency for all the quantity dried. It was also observed that at $50{ }^{\circ} \mathrm{C}, 200 \mathrm{~g}$ weight dried, the highest efficiency of $84.87 \%$ was obtained and reduced for $300 \mathrm{~g}$ and $400 \mathrm{~g}$. This might be due to the fact that Iru Pete has more moisture than the other type and so at reduced weight, it dried faster. The Iru Pete dried at $55^{\circ} \mathrm{C}$ has no significant difference in quantity $200 \mathrm{~g}$ and $300 \mathrm{~g}$ as compared to the $400 \mathrm{~g}$. The efficiency increased with increased drying temperature and drying time. This is in confirmation of the finding of Olalusi et al. (2006).

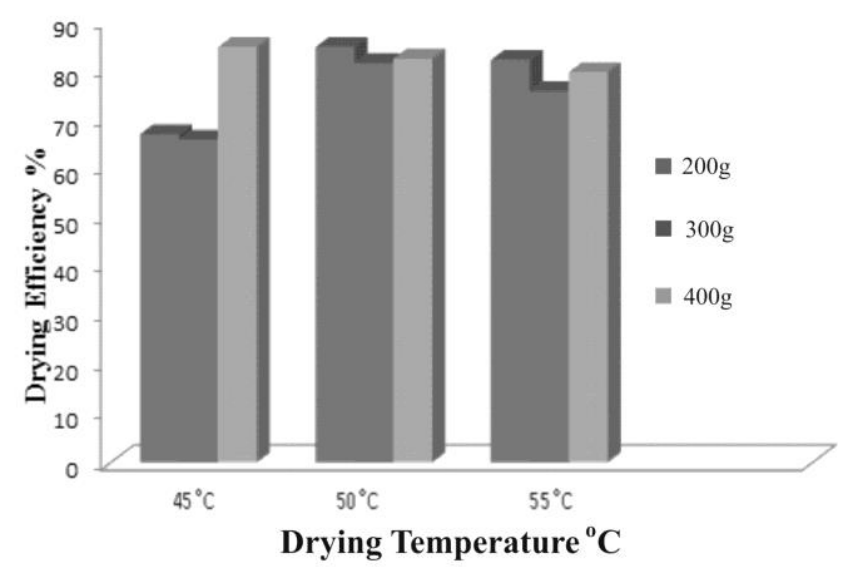

Figure 8: The effects of Drying Temperature on the Drying Efficiency of the Dryer for Iru Woro

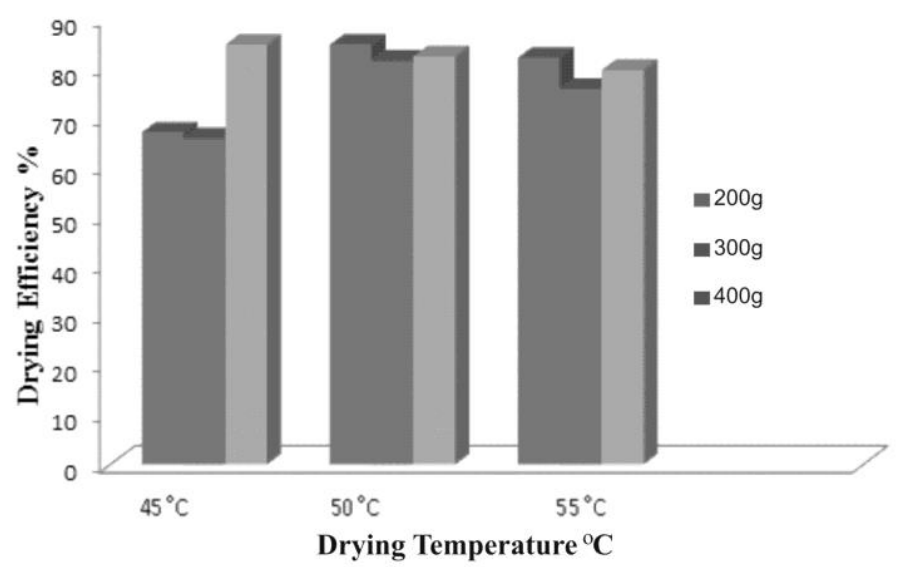

Figure 9: The effects of Drying Temperature on Drying Efficiency for Iru Pete 


\section{CONCLUSION}

The performance evaluation of the instrumented dryer developed recorded the following conclusions that the:

i. drying of fermented locust beans at the different drying temperatures $45^{\circ} \mathrm{C}, 50^{\circ} \mathrm{C}$ and $55^{\circ} \mathrm{C}$ occurred in a falling rate period, this shows that the drying phases play an important role in the design and fabrication of a dryer;

ii. increase in the drying temperature irrespective of the varieties and treatments led to the decrease in drying time; and

iii. efficiencies at the various drying temperatures and varieties ranged from $65.60 \%$ $84.87 \%$. Iru Pete had the lowest efficiency for the quantity dried of $400 \mathrm{~g}$ at $50{ }^{\circ} \mathrm{C}$.

\section{REFERENCES}

Alonge, A.F and Hammed, R.O. (2007). A Direct Passive Solar Dryer for Tropical Crops. African Crop Science Conference Proceedings. 8:1643 - 1646.

Amer ,B.M.A., Hossain, M.A and Gottschalk. (2009). Design and performance evaluation of a new hybrid solar dryer for Banana. Journal of Energy Conversion and Management. 51(4):813 -820.

Folaranmi, J. (2009). Design, Construction and Testing of Simple Solar Maize Dryer. Leonardo Electronic Journal of Practices and Technologies. ISSN 1583 - 1078 (13):122 - 130.

Gatea, A.A.(2010). Design,Construction and Performance Evaluation of Solar Maize Dryer. Journal of Agricultural Biotechnology and Sustainable Development. 2(3). 39 - 46.

Hany, S.El - Messery and Gikuru, M. (2012). Comparison of a gas fired hot air dryer with an electrically heated hot air dryer in terms of drying process, energy consumption and quality of dried Onions Slices. African Journal of Agricultural Research. 7(31):4440 - 4452.

Kilic, A. (2009). Low Temperature and high velocity (LTHV) application in drying: characteristics and effects on Fish quality. Journal of Food Engineering. 91 (2009):173 - 182.

Mu'azu, K., Bugaje, I.M. and Mohammed, I.A. (2012).Performance Evaluation of Forced Air- Convection Vegetable Drying System. Journal of Basic and Applied Scientific Research. 2(3):2562-2568.

Mujaffer, S. Sankat, K. (2005). The mathematical modelling of the osmotic dehydration of shark fillets at different brine temperatures. Int. J. Food Sci. Tech., 40: 1 - 12.

Ndukwu,M.C. (2009.) Effect of Drying Temperature and Drying Air on the Drying Rate and Drying Constant of Cocoa Bean. Agricultural Engineering International the CIGRE journal. 6(1091)

Ogunleye, I.O. and Awogbemi, O. (2009).Methods of Preserving and Improving the Quality of Locust Beans. Advanced Materials Research Vols. 62-64. 226-233. (www.Scientific net).

Olalusi, A.P., Oyerinde, A.S and Ogunlowo, A.S. (2006). Design and Performance Evaluation of a Simple Cocoa Beans with a Reciprocating Stirring Device. Proceeding of Nigerian Drying Symposium. 67 72. 
Olaoye et al, 2014

Omodara, M.A., Olaniyan, A.M and Afolayan, S.S. (2011). Effects of Drying temperatures on Drying Rate and Quality of African Catfish (clarias garieppinus). Proceedings of the $11^{\text {th }}$ International Congress on Mechanization and Energy in Agriculture Congress. Istanbul, Turkey. $408-413$.

Opiriairi, P.P.(2008). Design Performance Evaluation and Mathematical Modeling of a Shelled Corn Dryer. Unpublished M.Sc. Thesis, Agricultural and Environmental Engineering Department, University of Ibadan.

Earle, R. L. and M. D. Earle. (2004). Unit operations in food processing-2004 Web Edition. The New Zealand Institute of Food Science \& Technology (Inc.). http://www.nzifst.org.nz/unitoperations/about.htm 